\title{
Populism in France
}

\author{
Gilles Ivaldi, URMIS, CNRS-University of Nice \\ gilles.ivaldi@unice.fr
}

This is a pre-print version of: Ivaldi, Gilles, "Populism in France", which has appeared as a book chapter in: Daniel Stockemer (ed.) Populism around the world: A Comparative Perspective, Cham: Springer, pp.27-48 (https://www.springer.com/us/book/9783319967578)

\begin{abstract}
This chapter examines the supply and demand sides of populism in France. It looks at the two main populist actors i.e. the Front National (FN) and La France Insoumise (LFI). The FN exemplifies the typical radical right populist organization, primarily mobilizing grievances over immigration, while LFI shows a left-wing egalitarian and socially inclusive profile. Electoral support for populism in France is fuelled by economic instability and voter distrust of mainstream politics and of the EU. Both LFI and the FN increasingly converge on a common protectionist platform, opposing the EU and globalization. Populist voting in 2017 is found predominantly amongst the youngest cohorts and it is strongly correlated with populist attitudes. FN voters are primarily found amongst the so-called 'losers' of globalization in the lower social classes, who are typically more anti-immigrant and more authoritarian. LFI attracts on the other hand a broader coalition of secularized voters in the middle and lower social classes, who are primarily motivated by economic concerns. Both FN and LFI voters are more Eurosceptic than the mainstream, and they share similar concerns about globalization.
\end{abstract}

\section{Introduction}

The rise of populism is one of the most significant phenomena in today's political world. In the last decade, populist parties have gained significance across Europe and America. In the European context, populist parties manifest themselves in both radical left actors such as Podemos in Spain and SYRIZA in Greece, and radical right variants such as the French Front National (FN), the Austrian FPÖ and the Dutch Party for Freedom (PVV).

France is no exception to the current populist wave. Populist parties have made significant gains in the 2017 elections. To the left, populism is found in Jean-Luc Mélenchon's La France Insoumise (Rebellious France, LFI) while right-wing populism manifests itself predominantly in Marine Le Pen's Front National (National Front, FN). Mélenchon won 19.6 per cent of the 2017 first round presidential vote, taking the fourth place. To the right, Marine Le Pen won 21.3 per cent, progressing into the run-off where she received 33.9 per cent against the centrist and pro-EU candidate Emmanuel Macron. Overall, including other minor organizations, populist parties captured over 45 per cent of the 2017 presidential vote. 
France provides therefore a relevant case study for the analysis of the resemblances and dissimilarities of various manifestations of the populist phenomenon. This chapter examines the political supply of and demand for populism both left and right in France. The first section provides a definition of populism and identifies the main populist actors in French politics. The chapter then turns to the analysis of the current supply of populism and variety of populist actors and strategies in French politics. The third section examines the electoral basis and dynamics of support for populist parties. Finally, the chapter discusses the implications of the current rise of populism in French politics and society.

\section{Populism in France}

Mudde (2004) defines populism as a 'thin-centred ideology' which "considers society to be ultimately separated into two homogeneous and antagonistic groups, 'the pure people' versus 'the corrupt elite', and argues that politics should be an expression of the volonté générale (general will) of the people" (p.543). Populist parties vilipend the political elite as an oligarchy and separate 'caste', while simultaneously claiming to represent the 'ordinary people' (Stanley 2008).

Populist agendas and strategies vary considerably across parties and contexts, however. In the literature, this variance has been primarily associated with the thicker ideologies to which populism is anchored. As a thin-centered ideology, populism must attach itself to other more substantial sets of ideas which give it a full meaning (Mudde 2004). In the West-European context, populism is predominantly found in the radical left and radical right (Rooduijn and Akkerman 2017). In the radical right, populism is combined with nativism and authoritarianism, and it is culturally exclusionist (Mudde 2007). The radical left presents on the other hand a universalistic profile, embracing a more socially inclusive notion of the people which is essentially pit against an economic elite (Mudde and Kaltwasser 2013, Gómez-Reino and Llamazares 2016).

Existing research on the ideological profile of populist voters suggests variability in the issues and attitudes that motivate support for the populist radical right and left, respectively (Ivaldi 2017, Rooduijn et al. 2017). Supporters of the populist radical right show higher levels of cultural exclusionism and they distinguish themselves from other electorates by their opposition to immigration and a multicultural society, while economic equality and support for redistribution are the most distinctive features of left-wing populists (Van Hauwaert and Van Kessel 2018).

Historically, both the left and right variants of populism have been found in France since WWII, and they have manifested themselves across a variety of movements and parties. In the mid-1950s, the Poujade movement was the first instance of right-wing anti-tax populist organization, mobilizing small-town rural shopkeepers and small farmers who felt threatened by economic modernization and the rapid process of industrialization (Birnbaum 2012a: 96/98). During the 1990s, a growing opposition to European integration within the ranks of the French right created a favorable context for populist mobilization (Ivaldi 2006). This 
resulted in the formation of a number of 'sovereignist' and Eurosceptic groups with a strong populist appeal such as Philippe de Villiers' right-wing conservative Mouvement pour la France (Movement for France, MPF), and the small Chasse, Pêche, Nature, Traditions (Hunting, Fishing, Nature, Tradition party, CPNT) which emerged as a single-issue shooters' rights group in the $1980 \mathrm{~s}$, before turning into a more distinctly populist agrarian party.

Turning to the left of the political spectrum, populism was found in the Parti Communiste Français (French Communist Party, PCF). The PCF emerged from the Second World War as the dominant party of the French Left, and it was a significant vehicle for protest politics until the 1980s, polling between 20 and 25 per cent of the vote across legislative elections. While a Marxist party, the PCF showed some elements of populism, notably formulating a Manichean opposition between the ruling 'caste' and all the 'hardworking people' (Birnbaum 2012a: 122). During the 1990s, Communist dominance was challenged by new anti-globalization and anti-capitalist movements such as ATTAC and José Bové's Confédération Paysanne, which adopted a strong radical left profile and a populist orientation. Other challenges included populist entrepreneurs such as former businessman and TV host Bernard Tapie. The latter ran a populist campaign during the 1994 European elections, winning 12 per cent of the vote, vilipending the political 'elite both left and right', the 'technocrats' and the 'little aristocracy' which, he said, 'confiscate power at the expenses of the people' (Birnbaum 2012a: 270). In the late 2000s, the PCF was challenged further by the rise of far left parties such as the Nouveau Parti Anticapitaliste (New Anticapitalist party, NPA).

Two parties currently dominate the populist scene in France, namely the FN and LFI. Other more marginal populist actors include the NPA to the left, and Debout la France (DLF) to the right of the political spectrum.

The FN exemplifies the typical radical right-wing variant of populism (Mudde 2007). The FN was born in 1972 from small nationalist organizations. Since the mid-1980s, the FN has established itself as a significant force in French politics. In 2011, Marine Le Pen replaced her father as party leader. As Ivaldi (2016) suggests, the current FN operates on the core defining anti-elitist and people-centered features of populism. A central populist claim of the FN is that it authentically represents the will of the people against the political elite embodied by the socalled 'UMPS caste'. Le Pen's 2017 manifesto claimed to "give France its freedom back and give the people a voice". The FN's idealized people is constructed as the 'silent majority' (majorité silencieuse), referring to all the 'left behind', the 'invisible' and the 'forgotten ones who have been abandoned by political elites', and who, according to the FN, embody a 'generous and hard-working France' ${ }^{1}$. The FN accuses news media, journalists and intellectuals of being complicit with the political elite and financial powers ${ }^{2}$.

\footnotetext{
${ }^{1}$ Marine Le Pen, Speech in Brachay, 3 September 2016, http://www.frontnational.com/videos/discours-derentree-politique-de-marine-le-pen-a-brachay-2/ (last accessed: 8 April 2017).

${ }^{2}$ Marine Le Pen, Speech in Nantes, 26 February 2017, http://www.frontnational.com/videos/discours-de-marinele-pen-a-nantes-26022017/ (last accessed: 10 April 2017).
} 
To the left, the main populist party is Mélenchon's LFI. The party was founded in February 2016 from the previous Parti de Gauche (PG), which had emerged from anti-globalization social movements during the campaign against the Lisbon Treaty in 2009. Together with the Communists, the PG had participated in the Front de Gauche (FG). LFI takes its inspiration from Podemos in Spain. It embraces the political philosophy of post-Marxist theorists Chantal Mouffe and Ernesto Laclau, whereby left-wing populism refers to a new form of political organization where the unity of progressive people is achieved by the determination of an adversary which is represented by neoliberal forces (Mouffe 2016).

LFI shows strong anti-establishment features. The party's discourse and ideology illustrate radical left populist mobilization which seeks to offer an alternative to the neoliberal hegemony. During the 2017 elections, Mélenchon called upon the 'era of the people' ( $L$ 'ère $d u$ peuple), politicizing the concept of dégagisme (to clear out politicians), which reiterated its 2012 populist rhetoric. Five years earlier, Mélenchon had run a strong populist campaign against the 'financial oligarchy' and the 'political elite', claiming that "all politicians should go away!" (qu'ils s'en aillent tous!) (Birnbaum 2012b). In 2017, Mélenchon pledged that he would "sweep away the oligarchy and abolish the privileges of the political caste", notably denouncing political corruption and the collusion with financial powers ${ }^{3}$. According to Mélenchon, the elite consists of a homogeneous economic, political and financial oligarchy. LFI's notion of the people is conceived on the other hand as a variety of social groups at the bottom of society, which are collectively defined as the plural 'people' (les gens).

Finally, other populist parties include DLF and the NPA. DLF is a small right-wing Eurosceptic (souverainiste) neo-Gaullist organization led by Nicolas Dupont-Aignan. It originated as a minority faction of the right in the late 1990s before launching itself as an autonomous Eurosceptic party in 2008. During the 2017 elections, Dupont-Aignan repeatedly attacked the "political caste that no longer wish to talk to the French and does not listen to them anymore" 4 . He won 4.7 per cent of the vote in the first round of the 2017 presidential election, and he endorsed Marine Le Pen in the run-off.

To the left, a populist appeal is found in the NPA, a small far left party with a Trotskyite background. According to March (2012), the NPA fits the model of the 'populist socialist' party which combines a democratic socialist ideology with a strong anti-elite appeal and the claim to be the defenders of the 'ordinary people'. In the 2017 elections, the NPA candidate, Philippe Poutou, won $1 \%$ of the vote.

\footnotetext{
${ }^{3} \mathrm{https}$ ://laec.fr/section/2/balayer-l-oligarchie-abolir-les-privileges-de-la-caste

${ }^{4} \mathrm{http}$ //video.lefigaro.fr/figaro/video/nicolas-dupont-aignan-denonce-une-caste-politique-qui-n-ecoute-plus-lesfrancais/5394117468001/
} 


\section{Populist Agendas and Strategies}

Contemporary French populism is distributed along the structural left-right conflict, and populist parties are embedded in the existing party sub-systems of the left and the right. LFI presents a radical left profile and its populism operates primarily along socio-economic lines. LFI's economic populism embraces socialism against the neoliberal establishment. Since 2012, Mélenchon's policy package has been inspired by 'alternative' economists such as Jacques Généreux. During the 2017 campaign, Mélenchon’s populist profile was mired in controversy over his promise to take French Guyana into the Bolivarian Alliance for the Peoples of Our America (ALBA), set up by Cuba's Fidel Castro and Venezuela's Hugo Chavez in $2004^{5}$.

LFI strongly opposes austerity and it advocates economic redistribution, public spending and state intervention in the economy. In 2017, Mélenchon's platform ' $L$ 'avenir en commun' pledged to reduce socio-economic inequalities, promising to 'eradicate poverty and unemployment', to raise the highest tax rate at $90 \%$ and to put forward a $€ 100 \mathrm{bn}$ state investment plan. LFI's economic policies included higher taxes on capital, the expansion of public services, nationalizing the banking sector to fight speculation, raising lower wages, and reducing the retirement age to 60 . LFI advocates increased workers' rights and it strongly opposed the 2016 labor law for labor market flexibility.

Additionally, the 2017 platform emphasized environmental issues, attesting to the more general 'greening' of left-wing politics in France. Mélenchon moved towards an 'ecological transition', advocating a wide range of green policies while embracing ecological sustainability and a complete phase out of nuclear power by 2050, one of the issues that had opposed Mélenchon to his former Communist allies. Finally, LFI shows a predominantly libertarian-universalistic profile of social inclusion, defending the rights of immigrants and minorities in French society, although this profile has been toned down recently in response to growing immigration fears among voters. In 2017, LFI promised nevertheless to repel the more stringent national security laws passed by the dominant parties of both the right and left since 2007.

On the other hand, the FN exemplifies the typical populist radical right agenda which is dominated by nativism and authoritarianism (Ivaldi 2016). Le Pen's campaign of 2017 emphasized typical FN nativist policies calling for 'national priority' to the French in jobs, housing and welfare, and pledging that the principle of 'national priority' should be enshrined in the Constitution (FN 2017). Le Pen advocated a drastic reduction in immigration, as well as a range of measures to combat the so-called identitarian closure (communautarisme) of French Muslims. In the final stage of the campaign, she called for "an immediate moratorium to stop all legal immigration", arguing that "mass immigration is not a chance for France, but an oppression and a tragedy"'. Le Pen pledged also that she would close all 'extremist'

\footnotetext{
${ }^{5}$ http://www.lemonde.fr/election-presidentielle-2017/article/2017/04/14/qu-est-ce-que-1-alliance-bolivariennepour-les-ameriques 5111256 4854003.html

${ }^{6}$ http://www.frontnational.com/videos/grand-meeting-de-marine-le-pen-au-zenith-de-paris/
} 
mosques and that anyone associated with the Jihadist movement would be stripped of their French citizenship and deported.

In the context of the economic crisis, the FN has moved towards the left on the economy (Ivaldi 2015). Its current program shares some similarities with the left -e.g. lowering the retirement age to 60, increasing social spending minima and repealing the 2016 labour law. Under the leadership of Marine Le Pen, the party has embraced economic populism, claiming to defend all the 'little' and 'hardworking' people. The FN has adopted a Keynesian platform of redistribution and state regulation, and it advocates bolstering public services. In 2017, Le Pen ran on a heterogeneous economic platform, mixing social redistribution and state intervention with more market liberal measures for small entrepreneurs, thus seeking to address the needs of both her working class and petty-bourgeois electorates (Evans and Ivaldi 2018).

\section{Populists against the EU}

Populist parties both left and right increasingly converge on a common protectionist agenda. They oppose European integration and economic globalization, while operating on patriotism and the defense of national interests (Ivaldi et al. 2017). In the French context, both LFI and the FN show strong opposition to economic globalization and neoliberal capitalism. Both parties target free trade, large businesses, capitalist elites and financial international institutions. They manipulate Eurosceptic frames for voter mobilization, although the arguments they use against the EU and the intensity of their opposition to European integration vary.

The FN has espoused Euroscepticism since the mid-1990s (Hainsworth et al. 2004). FN's opposition to European integration taps into a wide range of institutional, economic and cultural issues (Ivaldi 2018). The EU is castigated by the FN as an elite-driven project and a 'totalitarian jail' for the people. It is also blamed for its agenda of free circulation and immigration, which according to the FN, is leading to a 'Europeist and multicultural magma'. Finally, the EU is vilified as the incarnation of neoliberalism and it is depicted as 'the first step towards savage globalization' (Ivaldi 2018). In 2017, Le Pen's presidential campaign claimed that France should restore national sovereignty over laws, borders and currency, while also opposing free trade agreements such as TAFTA and CETA (FN 2017). The campaign reiterated the party's previous claim to hold a French referendum on EU membership within six months in the presidency, so that the French could "emerge from this nightmare and become free again"7.

In LFI, Euroscepticim is primarily motivated by economic arguments. Since 2009, the PG has been a significant driver behind the contestation of globalization, international free-trade agreements and the EU, arguing that European integration is too market liberal. Its critique focuses on the EU's austerity policies and agenda of fiscal orthodoxy, strongly objecting to

\footnotetext{
${ }^{7}$ Marine Le Pen, Speech in Lyon, 5 February 2017, http://www.frontnational.com/videos/assises-presidentiellesde-lyon-discours-de-marine-le-pen/ (last accessed: 9 April 2017).
} 
labor market liberalization and privatization of public services. In the lead-up to the 2017 elections, Mélenchon shifted to a harder Eurosceptic stance, promising to renegotiate European treaties and threatening to take France out of the EU if negotiations failed ${ }^{8}$. The 2017 platform opposed what was deemed the 'tyranny' of the EU, suggesting that France should 'disobey' the European treaties to 'preserve the national sovereignty of the French people' 9 .

The 2017 platform strongly objected to international trade agreements such as TAFTA and CETA, calling for 'equitable protectionism' in order to relocate production and jobs in France. Mélenchon's B-plan included the suspension of France's contribution to the EU's budget, transforming the Euro into a common currency and re-establishing controls over the free movement of capital and goods. Additionally, the party claimed that the European Central Bank should no longer be independent, and it called for a moratorium on national debts within the Eurozone.

\section{National interests}

In both LFI and the FN, Euroscepticism is associated with patriotic claims and the defense of national interests (e.g. De Cleen and Stavrakakis 2017). Nationalism is typically found in the radical right's nativist ideology (Mudde 2007), but it is increasingly relevant to other populist manifestations located to the left of the political spectrum, such as the M5S in Italy and Podemos in Spain (Gerbaudo and Screti 2017, Ivaldi et al. 2017).

In France, Mélenchon has recently adopted a patriotic tone, advocating for the defense of national interests. LFI's patriotism defends the 'homeland' against foreign forces of globalization. During the 2017 presidential election, Mélenchon regularly resorted to patriotic values and claims. The traditional iconography of the French radical left, such as red flags and singing the Internationale, almost disappeared from LFI's meetings, and they were replaced with tricolor flags and the national anthem. References to the 'homeland' were paramount during the campaign. According to Mélenchon: "now is the time to show what the sovereign people are worth. The ballot papers must be used for a sweep that makes all of them [politicians] go away, without exception (...) They must all go away so that we can abolish the privileges of finance, those of the insolent caste that occupies all the powers, those of the presidential monarchy and of all the luxurious suites of the capital. We must think big for the French people, for our homeland"10. This was illustrated also in Mélenchon's first-round concession speech in which he made a vibrant call to his 'beautiful country and homeland', while simultaneously vilipending the 'mediacrats and oligarchs'"

\footnotetext{
${ }^{8}$ http://melenchon.fr/2016/06/24/lunion-europeenne-on-change-on-quitte-Iheure-plan-b-sonne-2017/

9 https://laec.fr/section/49/prendre-les-mesures-immediates-et-unilaterales-de-sauvegarde-desinterets-de-la-nation-et-d-application-de-notre-projet

${ }^{10} \mathrm{https}: / /$ melenchon.fr/2017/03/18/defile-6e-republique-18-mars-a-paris/

${ }^{11}$ http://www.ouest-france.fr/elections/presidentielle/presidentielle-jean-luc-melenchon-chacun-sait-quelest-son-devoir-4945769
} 
LFI's 2017 presidential platform showed some departure from the universalist tradition of French socialism. In particular, LFI de-emphasized its previous pro-immigration policies such as its 2012 claim to regularize all undocumented migrants. In 2012, Mélenchon celebrated ethnic diversity and multiculturalism, portraying immigration as an 'opportunity' for the country while denouncing the "morbid and paranoid idea of a choc of civilizations"12. The 2012 platform stated that "immigration was not a problem", denouncing "the myth of zero immigration, which weakens and divides our country" 13 . In contrast, the 2017 campaign clearly acknowledged growing immigration fears among lower and middle class voters which form the core electoral support of LFI. Mélenchon claimed in particular that France should immediately opt out from the EU directive on posted workers. Already during the 2015 refugee crisis, Mélenchon had taken a more ambiguous stance, criticizing Germany's decision to accept large numbers of refugees and arguing that "this was not the solution to the problem" ${ }^{14}$. In a controversial speech in the European Parliament in July 2016, Mélenchon had denounced a Europe of "social violence where posted workers come and steal the bread from local workers" 15 .

Patriotism and national sovereignty claims are central to FN mobilization strategies, and they are attached to the party's nativism. The elite is stigmatized by the FN for its allegiance to the so-called 'globalist and multiculturalist ideology' against which the FN pits itself as the only authentic 'patriotic' force. As explained by Le Pen in her 2017 manifesto, "this presidential election features two opposite projects - the 'globalist' choice represented by all my opponents- (...) and the 'patriotic' choice which I personify" (FN 2017).

\section{Populist Strategies}

Both the FN and LFI rely on anti-political-establishment mobilization, and both parties have made significant electoral gains recently by mobilizing voter discontent with mainstream politics. In both parties, the supply of populism is part of a broader strategy which seeks to overcome their minority status and replace the established party within their respective party sub-system. While LFI operates primarily to the left of the French party system, the FN has a broader appeal that cross-cuts the political boundaries, getting its support from voters across both sides of the spectrum (Perrineau 2017).

During the 2017 elections, LFI pursued a predominantly adversarial strategy against the proximal socialists, which contrasted with the more conciliatory approach that Mélenchon had adopted five years earlier, when he had endorsed the socialist candidate François Hollande in the presidential runoff. Soon after Hollande's election in 2012 however, co-operation with the PS became a major divisive issue between Mélenchon and his communist partners, creating

\footnotetext{
12 http://www.jean-luc-melenchon.fr/2012/04/14/discours-sur-les-plages-du-prado-a-marseille/

$13 \mathrm{https} / / /$ melenchon.fr/wp-content/uploads/2015/10/humain_dabord.pdf

${ }^{14}$ http://www.lefigaro.fr/politique/le-scan/2015/09/11/25001-20150911ARTFIG00089-pour-melenchonaccueillir-les-refugies-n-est-pas-la-reponse-au-probleme.php

$15 \mathrm{http}: / /$ www.europarl.europa.eu/sides/getDoc.do?pubRef=-//EP//TEXT+CRE+20160705+ITEM-005$01+\mathrm{DOC}+\mathrm{XML}+\mathrm{V} 0 / / \mathrm{FR} \&$ language $=$ fr\&query $=\mathrm{INTERV} \&$ detail $=2-192-000$
} 
in-fighting within the FG coalition. In 2016, the founding of LFI marked a significant turn in Mélenchon's strategic orientation. Despite repeated calls from Hamon during the campaign, Mélenchon decisively turned his back on an alliance with the PS. Between the two rounds of the presidential election, Mélenchon refused to endorse either of the two finalists, which provoked turmoil within LFI's ranks as well as among his communist allies. This strategy was reiterated in the legislative elections where LFI ran independently across the vast majority of constituencies, competing against both the PS and the Communists.

Turning to the radical right, anti-establishment populism has been a typical feature of the FN since its electoral breakthrough in the mid-1980s. Following Marine Le Pen's accession to the party leadership in 2011, the FN has pushed a strategy of 'de-demonization' which aims primarily to detoxify the party's extremist reputation and enhance its credibility to increase its appeal to moderate voters. An important aspect of steering away from the 'old' party was the decision by Marine Le Pen in August 2015 to expel Jean-Marie Le Pen from the FN, after he had reiterated his controversial views that Nazi gas chambers were a "detail of the Second World War" ${ }^{16}$. However despite the moderation of its rhetoric and policies, the current FN retains its previous radical right-wing populist profile (Ivaldi 2016). The FN portrays itself as a third competitive bloc in French politics, violently opposing both the left and the right -the so-called 'UMPS caste'-, and refusing to co-operate with other actors in the party system.

Because of its reputation as an extreme right party, the FN represents the archetypal 'political pariah' secluded behind a cordon sanitaire, and it has virtually no coalition potential at the national level. The political isolation of the FN was recently confirmed by the 2015 local and regional elections. Despite consolidated electoral returns, the FN failed to take local and regional executives, confronting a Front Républicain locally, that is the alliance of all major parties against the FN in decisive run-offs. The Front Républicain was reiterated in the 2017 presidential runoff where nearly all French parties called for a vote against Le Pen (Evans and Ivaldi 2018).

FN's populist strategies emphasize strong leadership and direct democracy by means of popular referendum. The FN exemplifies the populist illiberal democracy, showing distrust of pluralism and institutional mediations. The party criticizes established representative democratic institutions, international laws, intermediary bodies and constitutional courts (Ivaldi 2016). In contrast, the populist democracy of LFI is one of grassroots participation and direct involvement, relying heavily however on Mélenchon's charismatic leadership. Since 2012, Mélenchon has been advocating a radical transformation of the political system, emphasizing a move towards a 'Sixth Republic' whereby the current 'presidential monarchy' would be abolished. During the 2017 campaign, Mélenchon pushed a strong anti-corruption agenda, advocating also for proportional representation and the right for citizens to recall elected representatives.

\footnotetext{
${ }^{16}$ French National Front expels founder Jean-Marie Le Pen, $B B C, 20$ August 2015 (http://www.bbc.com/news/world-europe-34009901).
} 


\section{The Populist Agency: Organizational Basis}

Finally, the FN and LFI diverge in their models of party organization. Reflecting its emergence from the anti-globalization social movement, LFI has adopted grassroots-oriented participatory democracy, which takes its inspiration from Podemos in Spain. The organization of LFI relies primarily on local participatory assemblies (Groupes d'appui), bottom-up decision making, and free online membership. LFI's platform $L$ 'avenir en commun was adopted at the party convention in Lille in October 2016 by an Internet vote by 77,000 party sympathizers. The party's presence on the internet is achieved through various websites and social media venues, most notably the Discord online discussion forum which, according to the figures released during the 2017 campaign, has about 270,000 supporters. The platform was used for the internet vote by 243,000 supporters of LFI before the presidential runoff, to decide on the party's endorsement strategy ${ }^{17}$.

While emphasizing grassroots participation, LFI operates on more traditional top-down mechanisms associated with Mélenchon's personalistic, plebiscitarian style of political leadership. This was exemplified by Mélenchon's decision to run in the presidential election, for which no membership vote was taken. The personalization of LFI's leadership was illustrated further during the campaign when Mélenchon used holograms to appear in presidential campaign rallies held in different cities simultaneously.

The FN exhibits an authoritarian style of leadership and a highly centralized hierarchical party organization. The current FN illustrates continuity in its organization despite the change in party leader, which occurred in 2011. The party relies on a small grassroots base of about 50,000 members. In addition, the FN has been undergoing a process of 'marinization' whereby Marine Le Pen has successfully replaced her father as charismatic leader, both inside and outside the party (Ivaldi and Lanzone 2016). Externally, the founding in 2012 of the Marine Blue Rally (Rassemblement Bleu Marine, RBM) attested to the persistence of the FN's model of personalistic leadership dominated by Le Pen herself. Internally, 'mariniste' elites occupy virtually all top-level positions within the national party, while rival factions have been marginalized. Factionalism has increased recently following Le Pen's disappointing performance in the 2017 election. In September 2017, Florian Philippot, a prominent leader of the mariniste faction, left the FN over disagreement about the party's strategy and EU policies.

\footnotetext{
${ }^{17}$ A total of $36.1 \%$ favoured a blank ballot, $29.1 \%$ were in favour of abstaining while another third (34.8\%) would officially endorse Macron.
} 


\section{Electoral Support for Populism}

Populist parties have made significant gains in the 2017 elections, capitalizing on the wave of discontent with mainstream parties among French voters. Mélenchon won 19.6 per cent of the first round vote in the 2017 presidential election, taking the fourth place. LFI's candidates received 11 per cent of the vote in the following legislative elections, resulting in 17 seats in the National Assembly. Marine Le Pen won 21.3 per cent in the first round of the 2017 presidential election. In the run-off against Emmanuel Macron, she received 33.9 per cent, which marked an unprecedented level of support for the radical right in France. In the legislatives, FN candidates totaled 13.2 per cent of the vote, winning 8 seats in parliament, a first since the mid-1980s when the FN had formed a group of 35 deputies, after the socialist government had changed the electoral system to proportional representation.

\section{The context of the 2017 elections}

Over the past decade, the rise of populist parties has been primarily fuelled by economic instability and voter discontent with mainstream politics. First, the impact of the 2008 global financial crisis has been strongly felt in France, leading the country into its worst economic recession since the end of the Second World War. Both the right and left in government have confronted rising unemployment, and they have adopted deeply unpopular austerity packages to reduce the state's deficit. Since 2015, the unfolding of the EU refugee crisis has become a catalyst for immigration fears and anxieties caused by Islamic terrorism. More generally, voter discontent with the EU's management of the crises has created favorable opportunities for populist mobilization against the political establishment and the European Union (Ivaldi 2018).

Distrust of mainstream politics and voter aspiration to political change were paramount in the 2017 elections. Hollande faced record political discontent, with approval ratings below 20 per cent throughout the second half of his presidency, down to only 14 per cent of positive ratings on the eve of the 2017 elections. To the right, the Republicans clearly failed to rebuild a credible opposition to the socialists, suffering the damage caused by political scandals, presidential rivalries and increased party factionalism since 2012 (Evans and Ivaldi 2018).

Looking across both Sarkozy and Hollande's presidencies, an average 60 per cent of voters said they "trust neither the left nor the right to govern the country", while an overwhelming 85 per cent would agree that "politicians do not really care about what people think". Voters showed high levels of pessimism about the future both for themselves and the country. Dissatisfaction with the way democracy works in France remained exceptionally high at about 60 per cent on average throughout both Sarkozy and Hollande's presidencies, culminating at 70 per cent on the eve of the 2017 elections ${ }^{18}$.

To the left, LFI mobilized primarily economic grievances amongst disgruntled socialist voters. Immediately after the 2012 elections, the PS had taken a clear social-liberal U-turn

${ }^{18}$ http://www.cevipof.com/fr/le-barometre-de-la-confiance-politique-du-cevipof/resultats-1/vague8/ 
causing political discontent with the government in the early stage of the presidency. Austerity measures, an unpopular pension reform and higher taxes seemed to contradict Hollande's campaign pledges of redistribution and equality, which alienated vast numbers of left-wing voters. Hollande's promise to curb unemployment also failed to materialize and unemployment remained at its highest throughout the presidency. Social unrest and political discontent amongst low and middle-class voters culminated in 2016, after the passing by Manuel Valls' government of the highly unpopular El Khomri labor law ${ }^{19}$. The latter was strongly criticized by all of the PS's allies such as the Greens and the PRG, creating also enormous turmoil inside the socialist party.

Turning to the FN, economic grievances and issues have been important factors of the electoral revitalization of the radical right in France since the early 2010s. During the last election cycle, support for the FN has been fuelled by feelings of economic alienation. The party has further widened its electoral base amongst working and middle-class voters, who are traditionally associated with the left in France, and it has attracted in particular a significant share of former socialist voters of 2012 (Perrineau 2017). Addressing the needs of those voters, the FN has adopted a more Keynesian approach, embracing state intervention and redistribution, which places the party to the left of the economic axis (Ivaldi 2015). The EU refugee crisis and the wave of Islamic terrorism have dramatically increased the salience of immigration issues. This has produced a propitious context for the FN, giving the party a substantial electoral boost in the 2015 regional elections at 27.7 per cent of the vote.

\section{Populist voting in France}

The current literature on populism suggests that there is variation in the socio-demographic make-up of the populist constituency according to left and right location in the party system, and that the attitudes and issues that motivate populist voters vary also (Ivaldi 2017, Rooduijn et al. 2017, Van Hauwaert and Van Kessel 2018).

This section examines the demand-side of populist mobilization, looking at commonalities and differences in the socio-demographic and attitudinal profile of populist voters in the 2017 French presidential election. This data is taken from a large representative national sample of 19,454 French presidential voters in a survey, conducted by BVA on behalf of the University of Nice and as part of the European project SCoRE between 11 May and 25 June $2017^{20}$.

The dependent variable is the recalled vote in the first round of the 2017 presidential election. The analysis provides two separate sets of models for Le Pen and Mélenchon's voters, which first include standard socio-demographics (gender, age, education, occupation, religion,

\footnotetext{
${ }^{19}$ The main objective of the 2016 labor reform bill was to loosen France's strict labor regulations and increase flexibility in the job market.

${ }^{20}$ Sub-national context and radical right support in Europe (https://www.researchgate.net/project/SCoRESub-national-context-and-radical-right-support-in-Europe ). This project is funded by the French Agence Nationale de la Recherche (ANR) as part of a 3-year Open Research Area (ORA) for the Social Sciences project.
} 
religiosity and patrimony), then add a 'root' political affiliation (left right ideology) and a set of economic and cultural attitudes that are relevant to the study of left and right-wing populism (e.g. economic redistribution, welfare chauvinism, authoritarianism, support for the EU and for economic globalization). The models also include the populism scale designed by Akkerman et al. (2014), which has been used extensively in recent research on the effect of populist attitudes on populist party support ${ }^{21}$. The details of all variables and their descriptive statistics are summarized in Table 1. Non-voters and non-responses are excluded from the models, resulting in a final analytical sample of 10,511 French voters.

Table 1. HERE

Table 2 below shows the results of the models of voting for Le Pen in the first round of the 2017 presidential. The socio-demographic model (1a) suggests only a marginal gender gap amongst Le Pen voters, which confirms that the FN has expanded its appeal to women, recently (Mayer 2013). Reflecting also the increase in support for the FN amongst younger voters, the model indicates that the probability to vote Le Pen decreases with age. The effect of age is partially visible in religion: religiosity negatively correlates with FN voting, and religious voters - who tend to be older- are less inclined to support Le Pen. This finding is also consistent with the fact that the FN under Marine Le Pen has moderated its conservative views regarding adoption and same-sex marriage for instance (Crépon 2015).

Table 2. HERE

The data confirms that FN populism is predominantly found among the lower socio-economic strata. Lower levels of education are strongly associated with voting for Le Pen, while people with a high school or a university degree are much less likely to support the FN. These divergences are reflected in the social class make-up of the 2017 Le Pen vote. Working class and lower middle class voters -notably female employees in the so-called 'service proletariat' (Mayer 2013)- are over-represented amongst FN voters, a finding which is consistent with the recent literature on radical right voting in France (Stockemer 2017, Gougou 2015). These are also voters with fewer economic assets - as revealed in the negative correlation between FN voting and patrimony.

The results in Table 2 corroborate that FN voting is strongly influenced by general ideological orientations. The AIC is significantly lower in model $1 \mathrm{~b}$ which introduces attitudinal predictors. Let us note that most of the socio-demographic variables retain their effect when controlling for attitudes and left-right ideology. Support for Le Pen is primarily motivated by immigration, law and order and internationalization issues. The FN typically attracts voters

${ }^{21}$ The summation scale constructed from the six populism items shows consistency with an alpha of 0.78 . 
with welfare chauvinist preferences, who are opposed to the EU, who show fears of globalization, and who hold authoritarian attitudes - measured here from the claim that what French society "really needs, instead of more 'civil rights', is a good stiff dose of law and order". Economic attitudes play a lesser role in explaining support for right-wing populism, on the other hand. Because of their working-class profile, FN voters are more likely to support economic redistribution, but the correlation is relatively weak. Overall, the 2017 data provides evidence that the FN draws most of its support from the so-called 'losers of globalization' amongst voters in the lower social categories, who are affected the most by modernization, economic competition and feelings of cultural insecurity. Finally, populism significantly increases the probability to vote for Le Pen and this holds true when controlling for key socio-demographic characteristics and political attitudes.

Turning to Mélenchon, model 2a in Table 3 suggests that support for left-wing populism in France is more male and that it is found predominantly amongst the youngest cohorts, thus corroborating that populism both in its left and right variants was an attractive choice to younger voters in the 2017 elections. LFI predominantly draws its support from secularized voters, which reflects the traditional antagonism between the left and Catholicism in France. Other religious affiliations are also more prone to LFI voting, which reflects Mélenchon's appeal to voters with an immigrant background, most particularly French Muslims ${ }^{22}$.

Table 3. HERE

LFI supporters show higher educational attainments compared with their FN counterparts and Mélenchon achieves a higher support amongst voters with a high school diploma. LFI voters do not fulfill the 'globalization loser' profile. There is no evidence of a strong social class electoral basis of left-wing populism: LFI draws its support from a broader coalition of voters across all social strata and the party is relatively more successful among middle-class voters with fewer economic assets, as revealed in the negative effect of patrimony on voting for Mélenchon. This corroborates the current literature which suggests that left-wing populist parties are increasingly tapping into wider sectors of the electorate, attracting significant shares of the middle and upper class electorate (e.g. Ramiro 2016) and voters with higher education (Rooduijn et al. 2017).

The ideological profile of LFI voters in model $2 b$ confirms that political and economic attitudes are crucial determinants of left-wing populist voting in France. There is a significant decrease in the AIC's value in model 2b. Mélenchon's supporters are unambiguously located to the left of the party system, and left-right affiliation is a strong predictor of LFI voting. As would be expected, a higher support for economic redistribution is typically found amongst LFI voters who are also significantly less authoritarian, rejecting in particular law-and-order claims.

22 http://www.pelerin.com/A-la-une/Sondage-exclusif-Vote-et-religions 
Mélenchon voters converge on the opposition to European integration and economic globalization. LFI voters show a higher level of Euroscepticism, and support for the EU typically decreases the likelihood to vote for Mélenchon. Similarly, the effect of seeing economic globalization as an opportunity for growth is statistically significant and support for LFI is less pronounced amongst voters with positive views about globalization. Cultural protectionism is not entirely absent from the attitudinal drivers of left-wing populism in France. Welfare chauvinism shows a weak negative correlation with LFI voting, which suggests that these voters may have more ambivalent views of immigration. This may be partly accounted for by Mélenchon's stance on immigration during the 2017 campaign. Finally, as was the case in the FN, populism is a significant factor of populist left voting, which suggests that both FN and LFI voters are more are more populist than supporters of the mainstream.

\section{Conclusion}

This chapter has examined the supply of populism and demand for populist alternatives in the 2017 presidential elections in France. Populist parties have become prevalent on both the right and left of French politics. The FN illustrates the typical radical right-wing variant of populism. Immigration and national identity are key issues for FN mobilization. LFI shows a clear left-wing egalitarian and socially inclusive profile resembling that of other left-wing populist organizations in Europe such as Podemos in Spain.

While they diverge in terms of their attaching ideologies, both parties exhibit the core generic anti-elite and people-centered features of populism, and they increasingly converge on a common protectionist platform. Both LFI and the FN oppose European integration, although they vary in the justification frames they employ, and in the intensity of their opposition to the EU. Both parties embrace a strong anti-globalization agenda, rejecting free-trade, international corporations and neoliberal capitalism. The current economic manifesto of the FN also shares similarities with that of the left, which increases populist convergence.

The electoral vitality of populism in France has been primarily fuelled by economic instability and profound voter disaffection with mainstream politics and with the EU. Populist entrepreneurs such as le Pen and Mélenchon have successfully politicized economic, cultural and political grievances, mobilizing voters who feel increasingly estranged from mainstream politics and discouraged about their future. Political discontent culminated in the 2017 elections, paving the way for a profound reshaping of the French party system (Evans and Ivaldi 2018).

What does the future hold for populism in France? The issues and grievances that drive support for populist parties, such as immigration, unemployment and social inequality, are unlikely to disappear and they should ensure the future relevance of the populist phenomenon in French politics. Moreover, both the governing PS and the Republicans have become weaker in the 2017 elections, which clearly produces opportunities for populists to try and occupy the political space left vacant by the 'old' dominant parties of the left and right. 
There are nevertheless a number of obstacles that may prove extremely difficult for populist parties to overcome. First, both LFI and the FN rely on relatively weak party organizations and a limited base of power locally, which impedes their ability to overcome their minority status in the party system. Second, both parties lack governmental credibility and valence. Their radical platforms veer towards the ideological periphery, attracting more extreme voters, which alienates moderates at the center of French politics. As was recently illustrated by the split of the Philippot faction, the FN is also divided over policies and strategies internally.

Most importantly, populist parties face important institutional hurdles. The majoritarian electoral framework in French politics poses serious challenges to outsider parties such as LFI and the FN. Political parties must build electoral cartels in order to achieve a majority in French elections. Because they operate primarily on adversarial anti-establishment strategies, populist organizations such as LFI and the FN fail to co-operate with mainstream parties. They play mostly a nuisance role in the party system, altering the balance between established parties and affecting the final results of elections. This power of nuisance was illustrated in the 2017 elections, where the rise in support for populist parties was sufficient to exclude both the PS and the Republicans from the presidential run-off.

Macron's victory and the building of a new centrist pole in French politics may pose additional competitive challenges to populist parties in the future. Macron's party currently occupies a winning strategic location at the vote-rich center ground of the political spectrum. LREM operates on a cross-cutting appeal to moderate voters from both the left and right, which gives the party a decisive advantage against radical alternatives. The future direction of the more polarized French party system that has emerged from the 2017 elections, hangs in the balance between the ability of populist organizations to transform themselves into more credible party alternatives, and the capacity of mainstream parties to offer responses to the issues and concerns of voters, who feel left behind in current globalization. 


\section{References}

Akkerman, A., Mudde, C. and A. Zaslove (2014) 'How populist are the people? Measuring populist attitudes in voters', Comparative Political Studies, 47(9), 1324-53.

Birnbaum, P. (2012a) Genèse du populisme. Le peuple et les gros. Paris: Pluriel.

Birnbaum, P. (2012b) 'La parabole de M. Mélenchon', Critique n776-777: 110-118

Crépon, S. (2015) 'La politique des mœurs au FN' in Crépon S., Dézé, A. and N. Mayer (eds.), Les faux-semblants du Front national, Paris: Presses de Sciences Po

De Cleen, B. and Y. Stavrakakis (2017) 'Distinctions and Articulations: A Discourse Theoretical Framework for the Study of Populism and Nationalism', Javnost - The Public, 24(4): 301-319

Evans, Jocelyn and Gilles Ivaldi (2018) The 2012 French Presidential Elections. A Political Reformation? Basingstoke: Palgrave MacMillan

FN (2017) 144 engagements présidentiels, Marine 2017

Gerbaudo, P. and F. Screti (2017). Reclaiming Popular Sovereignty: The Vision of the State in the Discourse of Podemos and the Movimento 5 Stelle. Javnost - The Public, 24(4): 320-335

Gómez-Reino, M. and I. Llamazares (2016) 'From Working-Class Anticapitalism to Populism: Theoretical Developments and Political Choices in the Birth of Podemos', Presented at the Team Populism Conference "Explaining Populism," Brigham Young University

Gougou, F. (2015), 'Les ouvriers et le vote Front National. Les logiques d'un réalignement électoral' in Crépon S., Dézé, A. and N. Mayer (eds.), Les faux-semblants du Front national, Paris: Presses de Sciences Po

Hainsworth, P., O'Brien, C. and P. Mitchell (2004) 'Defending the nation: the politics of Euroscepticism on the French right' in R. Harmsen and M. Spiering (eds)

Euroscepticism: Party politics, national identity and European integration, Amsterdam: Rodopi

Ivaldi, G. (2015). Towards the median economic crisis voter? The new leftist economic agenda of the Front National in France. French Politics 13(4): 346-369

Ivaldi, G. (2016) A new course for the French radical-right? The Front National and 'dedemonization' in T. Akkerman, S. de Lange and M. Rooduijn (eds) Radical RightWing Populist Parties in Western Europe. Into the Mainstream? Routledge, pp.231253

Ivaldi, G. (2017) Electoral basis of populist parties. In Heinisch, R., Holtz-Bacha, C. and O. Mazzoleni (eds.) Political Populism. A Handbook, Baden-Baden: Nomos, pp.157-168

Ivaldi, G. (2018) Contesting the EU in Times of Crises: The Front National and Politics of Euroscepticism in France. Politics, https://doi.org/10.1177/0263395718766787

Ivaldi, G. and M.E. Lanzone (2016) 'From Jean-Marie to Marine Le Pen: organizational change and adaptation in the French Front National' in Heinisch, R. and O. Mazzoleni (eds) Understanding populist party organization: a comparative analysis, Basingstoke: Palgrave

Ivaldi, G., Lanzone, M.E. and D. Woods (2017) 'Varieties of Populism Across a Left-Right Spectrum: the case of the Front National, the Northern League, Podemos and Five Star Movement', Swiss Political Science Review, 23(4): 354-376

March, L. (2012) Radical Left Parties in Europe. Abingdon: Routledge

Mayer, N. (2013) 'From Jean-Marie to Marine Le Pen: Electoral Change on the Far Right' Parliamentary Affairs, 66(1): 160-178

Mouffe, C. (2016) 'In defence of left-wing populism'. http://theconversation.com/in-defenceof-left-wing-populism-55869

Mudde, C. (2004). The Populist Zeitgeist. Government and Opposition 39(4): 542-563.

Mudde, C. (2007). Populist Radical Right Parties in Europe. Cambridge: Cambridge 
University Press.

Mudde, C. and C. Rovira Kaltwasser (2013). Exclusionary vs. inclusionary populism:

Comparing contemporary Europe and Latin America. Government and Opposition 48(2): 147-174.

Perrineau, P. (2017) Cette France de gauche qui vote FN. Paris: Le Seuil.

Ramiro, L. (2016) 'Support for radical left parties in Western Europe: social background, ideology and political orientations', European Political Science Review, 8(1), 1-23

Rooduijn, M. and T. Akkerman (2017) 'Flank attacks Populism and left-right radicalism in Western Europe', Party Politics, 23(3): 193-204

Rooduijn, M., Burgoon, B., van Elsas, E.J. and H.G van de Werfhorst (2017) 'Radical distinction: Support for radical left and radical right parties in Europe', European Union Politics, 18(4): 536-559

Stanley, B. (2008). The thin ideology of populism. Journal of Political Ideologies 13(1): 95110.

Stockemer, D. (2017) The Front National in France. Continuity and Change Under JeanMarie Le Pen and Marine Le Pen. Springer

Van Hauwaert, S. M. and S. Van Kessel (2018) 'Beyond protest and discontent: A crossnational analysis of the effect of populist attitudes and issue positions on populist party support' European Journal of Political Research, 57(1): 68-92 


\section{Tables}

Table 1. Summary of attitudinal indicators and descriptive statistics

\begin{tabular}{|c|c|c|c|c|c|c|}
\hline Dimension & Item & Measurement & Mean & $\begin{array}{l}\text { St. } \\
\text { Dev. }\end{array}$ & Min & Max \\
\hline Populism & Scale Akkerman et al. (2014) & Scale & 4.1 & 0.7 & 1 & 5 \\
\hline Left-Right & Left-right self-placement & low values $=$ left & 6.4 & 2.8 & 1 & 11 \\
\hline State intervention & $\begin{array}{l}\text { The less that government intervenes in } \\
\text { the economy, the better it is for France } \\
\text { [INV] }\end{array}$ & $\begin{array}{l}\text { low values }= \\
\text { disagree }\end{array}$ & 4.3 & 1.8 & 1 & 7 \\
\hline Redistribution & $\begin{array}{l}\text { The government should take measures } \\
\text { to reduce differences in income levels }\end{array}$ & $\begin{array}{l}\text { low values }= \\
\text { disagree }\end{array}$ & 5.7 & 1.5 & 1 & 7 \\
\hline $\begin{array}{l}\text { Welfare } \\
\text { Chauvinism }\end{array}$ & $\begin{array}{l}\text { When should immigrants receive } \\
\text { benefits }\end{array}$ & $\begin{array}{l}\text { low values }= \\
\text { earlier }\end{array}$ & 3.2 & 1.0 & 1 & 5 \\
\hline EU integration & $\begin{array}{l}\text { European unification should go } \\
\text { further }\end{array}$ & $\begin{array}{l}\text { low values }= \\
\text { disagree }\end{array}$ & 4.6 & 2.0 & 1 & 7 \\
\hline $\begin{array}{l}\text { Same sex } \\
\text { marriage }\end{array}$ & $\begin{array}{l}\text { It's a good thing that same-sex } \\
\text { marriage is equal to opposite-sex } \\
\text { marriage in the eyes of the law }\end{array}$ & $\begin{array}{l}\text { low values }= \\
\text { disagree }\end{array}$ & 5.1 & 2.1 & 1 & 7 \\
\hline Globalization & $\begin{array}{l}\text { Globalisation is an opportunity for } \\
\text { economic growth in France }\end{array}$ & $\begin{array}{l}\text { low values }= \\
\text { disagree }\end{array}$ & 4.6 & 1.7 & 1 & 7 \\
\hline Authoritarianism & $\begin{array}{l}\text { What our country really needs instead } \\
\text { of more 'civil rights' is a good stiff } \\
\text { dose of law and order }\end{array}$ & $\begin{array}{l}\text { low values }= \\
\text { disagree }\end{array}$ & 4.8 & 2.0 & 1 & 7 \\
\hline
\end{tabular}

$\mathrm{N}=10,511$ French voters 
Table 2. Logistic regressions of Le Pen voting in the 2017 French presidential elections

\section{Le Pen Vote}

\begin{tabular}{lcc}
\hline Constant & $-0.63^{* * *}$ & $-4.70^{* * *}$ \\
& $(0.22)$ & $(0.44)$ \\
Male(ref) & & \\
Female & -0.06 & 0.02 \\
& $(0.06)$ & $(0.07)$ \\
Age Continuous & $-0.02^{* * *}$ & $-0.04^{* * *}$ \\
& $(0.003)$ & $(0.003)$
\end{tabular}

Education None (ref)

Education Lower Sec.

$\begin{array}{ll}0.03 & -0.03 \\ (0.10) & (0.12)\end{array}$

Education BAC

$\begin{array}{ll}-0.49^{* * *} & -0.39^{* * *} \\ (0.10) & (0.12)\end{array}$

Education University

$\begin{array}{cc}-1.20^{* * *} & -1.00^{* * *} \\ (0.10) & (0.13)\end{array}$

Manag. Prof. (ref)

Independent

$0.75^{* * *} \quad 0.36^{*}$

(0.16)

$(0.20)$

Technician

$\begin{array}{ll}0.54^{* * *} & 0.43^{* * *} \\ (0.12) & (0.14)\end{array}$

Employee

$0.83^{* * *} \quad 0.62^{* * *}$

$(0.10)$

$(0.13)$ 
Worker

Retired

Inactive

Patrimony (0 to 5 assets)

Religion Other religion

Religion None (ref)

Religion Catholic

Religiosity Never

Populism

Left Right

State Intervention

Religiosity Regular (ref)

Religiosity Occasional
$1.00^{* * *}$

$0.76^{* * *}$

$(0.14)$

(0.17)

$0.40^{* * *}$

0.21

$(0.12)$

(0.14)

$0.39^{* * *}$

$0.32^{* *}$

$(0.13)$

(0.15)

$-0.20^{* * *}$

$(0.03)$

$-0.17^{* * *}$

$(0.04)$

$0.41^{* * *}$

$-0.08$

$(0.06)$

$(0.08)$

$0.32^{* * *}$

(0.12)

(0.15)

$0.33^{* * *}$

$0.64^{* * *}$

(0.13)

(0.15)

$0.42^{* * *}$

(0.06)

$0.30^{* * *}$

(0.01)

$-0.03$ 
$(0.02)$

Economic Redistribution

$0.08^{* * *}$

$(0.02)$

Welfare Chauvinism

$0.40^{* * *}$

$(0.04)$

European Integration

$-0.27^{* * *}$

$(0.02)$

Same Sex

$-0.06^{* * *}$

$(0.02)$

Globalization

Opportunity

$-0.23^{* * *}$

$(0.02)$

Authoritarianism

$0.28^{* * *}$

$(0.02)$

N

10,511

10,511

Log Likelihood

$-4,502.00$

$-3,060.00$

Akaike Inf. Crit.

$9,038.00$

$6,172.00$

Notes:

${ }^{* * *}$ Significant at the 1 percent level.

${ }^{* *}$ Significant at the 5 percent level.

*Significant at the 10 percent level. 
Table 3. Logistic regressions of Mélenchon voting in the 2017 French presidential elections

Mélenchon Vote

\begin{tabular}{lcc}
\hline Constant & $-1.00^{* * *}$ & 0.63 \\
& $(0.21)$ & $(0.39)$ \\
Male(ref) & & \\
Female & $-0.12^{* * *}$ & $-0.17^{* * *}$ \\
& $(0.05)$ & $(0.06)$ \\
Age Continuous & $-0.01^{* * *}$ & $-0.02^{* * *}$ \\
& $(0.002)$ & $(0.003)$
\end{tabular}

Education None (ref)

Education Lower Sec.

0.09

0.20

$(0.11)$

$(0.13)$

Education BAC

0.15

0.16

$(0.11)$

(0.13)

Education University

$0.02 \quad 0.06$

(0.11)

$(0.13)$

Manag. Prof. (ref)

Independent

$-0.20$

0.10

(0.17)

$(0.20)$

Technician

$\begin{array}{ll}0.33^{* * *} & 0.22^{* *} \\ (0.09) & (0.11)\end{array}$

Employee

$\begin{array}{ll}0.27^{* * *} & 0.23^{* *} \\ (0.08) & (0.10)\end{array}$


Worker

Retired

Inactive

Patrimony (0 to 5 assets)

Religion Other religion

Populism

Left Right

Religion None (ref)

Religion Catholic

Religiosity Regular (ref)

Religiosity Occasional
Religiosity Never

$\begin{array}{lc}0.26^{*} & 0.18 \\ (0.13) & (0.16)\end{array}$

$\begin{array}{ll}0.09 & 0.18\end{array}$

$(0.10)$

$(0.11)$

$0.23^{* *}$

0.13

$(0.10)$

$(0.12)$

$\begin{array}{ll}-0.19^{* * *} & -0.07^{* *} \\ (0.03) & (0.03)\end{array}$

$\begin{array}{cc}-0.71^{* * *} & -0.27^{* * *} \\ (0.06) & (0.07)\end{array}$

$0.23^{* *}$

0.21

(0.11)

$(0.13)$

$0.21^{*}$

0.005

$(0.12)$

$(0.14)$

$0.48^{* * *}$

$-0.01$

$(0.13)$

$(0.15)$

$0.45^{* * *}$

$(0.05)$

$-0.41^{* * *}$

(0.01) 
State Intervention

Economic Redistribution

Welfare Chauvinism

European Integration

Same Sex

Globalization

Opportunity

Authoritarianism

$N$

Log Likelihood

Akaike Inf. Crit.
$-0.03$

$(0.02)$

$0.22^{* * *}$

$(0.03)$

$-0.08^{* * *}$

$(0.03)$

$-0.12^{* * *}$

$(0.02)$

$0.04^{* *}$

$(0.02)$

$-0.13^{* * *}$

$(0.02)$

$-0.14^{* * *}$

$(0.02)$

10,511

10,511

$-4,975.00$

$-3,766.00$

$9,984.00$

$7,585.00$

Notes:

${ }^{* * *}$ Significant at the 1 percent level.

${ }^{* *}$ Significant at the 5 percent level. 